\title{
Sectarianism and Separatism in Colonial Port Phillip
}

\author{
Valerie Wallace \\ Victoria University of Wellington
}

\begin{abstract}
This paper assesses the sectarian dimension to the campaign in the 1840s for the separation of the Port Phillip district from New South Wales. It pays particular attention to the role in the campaign of the Rev. John Dunmore Lang and a Scottish Presbyterian lobby group whose commitment to Port Phillip's independence was driven by anti-Catholicism and a belief in church-state separation. The paper examines how race, class, gender and religion intersected in colonial discourse and asserts that the unity achieved during the campaign by European settlers at the expense of Indigenous Australians was temporary and fragile.
\end{abstract}

Europeans first settled the Port Phillip region, which evolved into today's Australian state of Victoria, around 1803. Settler expansion began in earnest c.1834 and the colonial authorities formally annexed and demarcated the region in 1836. As a region of New South Wales, the territory was governed as a crown colony; Charles La Trobe, appointed superintendent of the settlement in 1839, answered to the governor in Sydney. A campaign for Port Phillip's separation from New South Wales began as early as 1840 when a Separation Committee was constituted in Melbourne. Local residents and the municipal authorities in Melbourne, Bourke and Grant dispatched petitions for separation and political autonomy to the governments in Sydney and at Westminster. Separation, one contemporary stated, was a "watchword at Port Phillip; the conversation of every hour, a favourite channel for the flow of eloquence, and an expansive subject at the public meeting and the festive board."

Anti-separatists proclaimed that for Port Phillip and the middle district of New South Wales, "Union is strength." 2 But the separatists resented the re-routing of the region's resources to Sydney and other parts of the colony. They denounced the apparent self-interest and apathy of the Sydney establishment. Port Phillip, they said, was not just another district of New South Wales like Bathurst or Argyle, as anti-separatists claimed; it had its own harbour; thus, it had been designed by nature to be an independent region. ${ }^{3}$ The population had already 
reached 25,000 and, the separatists insisted, the colony could support itself from its abundance of natural resources. ${ }^{4}$ Sydney also was at least 600 miles from Melbourne; such a distance that none of Port Phillip's elected representatives could actually live there. In 1839 a group of Port Phillippians discontinued their subscriptions to the Sydney newspapers. It took so long for the papers to travel overland to Melbourne that residents got the Sydney news from the Launceston papers before the Sydney papers had arrived. ${ }^{5}$

The separatists were ultimately successful-Port Phillip became the autonomous colony of Victoria in 1850 - and they celebrated their victory at a parade in November to mark the opening of the Princes Bridge over the river Yarra. During the celebratory march, the St Patrick's Society displayed both Irish and British symbols. ${ }^{6}$ This parade and the separation campaign more generally were, Jessie Mitchell has argued, unifying moments for European settlers which permitted "a certain multi-cultural inclusion". The separation campaign enabled colonists to ignore their ethnic and religious differences and to forge a unifying identity in opposition to that of the Aboriginal "other." Written accounts of the colony's progress, Mitchell contends, either excised Indigenous people completely or emphasised instead their "savagery": Indigenous barbarism threw Port Phillip's urbanity into greater relief. ${ }^{7}$

This paper asserts by contrast that European settlers achieved merely temporary and fragile unity at the expense of Indigenous Australians. The article uncovers the sectarian dimensions to the Port Phillip separation campaign. It suggests that the multicultural symbolism on display during the Yarra parade masked tensions within the settler communitytensions particularly evident in the settlement's early years. It pays close attention to the role in the campaign of a Scottish Presbyterian lobby group whose commitment to Port Phillip's independence was partly driven by anti-Catholicism. Scots constituted at most only 10 percent of the Port Phillip population, but they were politically powerful. Five out of twelve of the elected members of the first Melbourne town council in 1842 were Scottish Presbyterians; these included the first mayor, Henry Condell, a local brewer, and William Kerr, a newspaper journalist from Stranraer on Scotland's west coast. Kerr voiced the opinions of the separatist lobby through the Port Phillip Patriot (1838-45), the Melbourne Weekly Courier (1845-46) and the Argus (1846-48). ${ }^{8}$ The Rev. John Dunmore Lang (1799-1878), controversial Scottish Presbyterian minister of Sydney and Kerr's "fast friend till death," 9 also became a public face of separation. Besides writing printed works, Lang pressed for separation as a member of the New South Wales legislative council, to which he was elected after its formation in 1842. After 
the council outvoted the measure, he urged the six Port Phillip representatives to draft their own petition for separation and dispatch it to London. A celebration held in Lang's honour in 1846 marked his role in the campaign for autonomy. ${ }^{10}$ Historians are now paying greater attention to Lang - for a long time overlooked as a politically irrelevant figure - and to the religious basis of his politics. ${ }^{11}$ This paper follows this trend first by examining how race, class, gender and religion intersected in separatist discourse and then by underlining the role of Scottish Presbyterian values, including a belief in church-state separation and loyalist mythology, in shaping the separatist campaign.

\section{Sectarianism in separatist discourse}

The 1832 Reform Acts, which defined British political citizenship as middle-class and male, established a new "bourgeois imperial culture of manners." In the wake of the acts, colonists in New South Wales, a region stained by its convict past where gender roles were reportedly confused, were particularly determined to project a respectable self-image and perform their masculine civility. ${ }^{12}$ Port Phillip was not burdened with a convict legacy; some separatists were thus determined to prevent the Randolph convict ship from docking in Melbourne when transportation recommenced in 1849. A separation petition from Port Phillip inhabitants pointed out that, unlike Sydney or Van Diemen's Land, Port Phillip was a free colony, preoccupied with elevating the moral and social scale of its inhabitants. ${ }^{13}$ In the 1850 s, the now-independent Victorian legislature introduced draconian laws aimed at curbing the migration of ex-convicts to Port Phillip from Van Diemen's Land-evidence of the moral panic which gripped the local population. ${ }^{14}$ Separatist narratives also drew on politicised census records - records from which Indigenous people were excluded - to highlight the growth of the region's White population. ${ }^{15}$ The message settlers aimed to convey was that, as a modernising and civilising settlement, Port Phillip deserved to manage its own affairs.

Census-taking was utilised not just to highlight the growth of the settler population and the decline of Indigenous Australians, but also to subordinate Irish Catholics. Though sensitive to the significance of class, race and gender in separatist discourse, historians have to some extent overlooked the importance of sectarian rhetoric and the ways in which religion

intersected with class, race and gender. ${ }^{16}$ The New South Wales census, reported in 1837 in the Sydney-based newspaper of John Dunmore Lang, categorised the colony's population as male and female, free and bonded and Protestant and Catholic. ${ }^{17}$ An article in Lang's paper complained that the Protestant and Catholic categories had not been further sub-divided into 
convict and free. It calculated that one-third of the convicts who had arrived in the last three years had been Irish Catholics and that they had been disproportionately punished for bad behaviour. ${ }^{18}$ In the opinion of Lang and others like him, the immigration of immoral Catholics who had, allegedly, a propensity to commit crime and lead debauched lives posed as much of a threat to the colony's reputation as did the existence of unconverted Indigenous "savages." As Hilary Carey has pointed out, Lang equated convictism with Catholicism; sectarianism underpinned his anti-transportation agenda ${ }^{19}$ as well as his commitment to the related issue of separation, as this paper will demonstrate.

Though accommodation of Catholics had emerged as official imperial policy at the turn of the nineteenth century, ${ }^{20}$ and despite examples of their political agency, ${ }^{21}$ Catholics continued to occupy a marginalised status in the Victorian period, a position reaffirmed with the onset of the Irish famine. The British government had emancipated Catholics in 1829, but the Irish franchise had been raised to prevent the Catholic population from mobilising politically. Indeed, as John Wolffe has argued, the emancipation of Catholics made it "doubly important" that Britain's Protestant identity "should be clearly reasserted."22 Catholics continued to occupy an ambiguous position within and outside the nation; "their forms of cultural belonging to that nation," Catherine Hall has written, were "strictly limited." 23 Some elements of the British public condemned Irish Catholics as a "contaminating" presence in the "social body." 24 Many regarded bourgeois morality, which encapsulated the virtues of modesty, cleanliness, hard work, sobriety, literacy and thrift, as specifically Protestant. ${ }^{25}$

As a resident of the west coast of Scotland before his own migration to Sydney, John Dunmore Lang witnessed first-hand the immigration of poor Irish Catholics into Scotland. As we shall see in succeeding sections, Lang was already predisposed to discriminate against Irish Catholics on account of his Scottish Presbyterian values-he was strongly influenced, for example, by the Reformation-era critique which labelled Catholicism a threat to civil and religious liberty - but now his anti-Catholicism became more vehement. He recommended that Irish migrants be charged a poor-rate on their arrival in Britain to "shut our ports effectually for the future against the further influx of Irish pauperism, degradation and crime." ${ }^{26}$ Irish Catholics, Lang thought, were also a danger to contemporary New South Wales including the burgeoning settlement of Port Phillip. Poor, promiscuous and lazy, Catholics threatened to undermine the colony's aspirations to bourgeois respectability and its chances of attaining autonomy. 
Though the formal petitions for separation made no mention of religious grievances, Lang's printed works suggested that separation was imperative in order to protect Port Phillip from the infusion of a corrosive Catholicism. In recent years, Lang explained, proceeds from the sale at public auction of "waste lands" had been paid into a land fund and devoted to the promotion of emigration to the district. Emigration and Land Commissioners in Britain had had the responsibility for selecting suitable migrants and had chosen them from across Britain and Ireland. Sydney merchants, however, had taken control of the land fund and had established links with emigration brokers in London whose activities went unsupervised by the government and whose main goal was to maximise profit. Their aim was to fill ships as cheaply and as efficiently as possible. These brokers made no effort to transport migrants from the north of Britain and instead sent ships from London to Plymouth, a port easily accessible by Irish steamboats, and thus most migrants supplied under this bounty system hailed from Dublin, Cork, Limerick, Galway and Tipperary. Of the migrants sent out between January 1841 and June 1842, Lang claimed, over 60 percent came from Ireland; on the ship on which he travelled in 1840 , only one out of eighteen was Protestant. ${ }^{27}$

Entirely unsuitable, these migrants put the colony's political future at risk. Immigration, Lang argued, should raise "the tone of moral feeling" in a colony which had, on account of its convict heritage, been depicted in Britain as a "sink of pollution." Employers were reluctant to hire Catholic migrants, "persons in the most abject poverty, and in the lowest stage of moral debasement." These migrants hailed from counties known to be hubs of popery and immorality; Tipperary was infamous for the violent crimes perpetrated there. The boats which carried migrants to Plymouth usually transported pigs and cattle; these individuals, Lang implied, were little better than hogs. The encouragement of Irish migration to New South Wales would, Lang concluded, "blast the hopes and ruin the morals of the Colony for all time coming." 28 It was an outrage, Lang thought, that funds generated in Port Phillip through land purchases made by Protestants should have been used to fill those lands with Catholics. It was thus crucial for Port Phillip to secure its autonomy from Sydney and regain control of its own land fund.

Irish Catholics were thus discriminated against by Lang and other separatists owing to their status as a poverty-stricken underclass; this prejudice, however, can also be attributed to ideas of "racial differentiation." As Dianne Hall has pointed out, in colonial Australia, "the 
biggest minority group of settlers with 'white' skin, the Irish, were represented as racially, culturally and socially different" from the dominant and allegedly more civilised Anglo-Saxon Briton. Only at the turn of the twentieth century were Irish Catholics labelled as "white Australians." 29 In the nineteenth century, contemporary cartoons underlined the distinguishing bodily features of Irish Catholics thus locating the group close to Indigenous Australians on a constructed racial scale. During the separation debate, in an attempt to discredit both communities, contemporaries drew comparisons between Irish Catholics and Aboriginal Australians.

Indeed, Irish Catholics were, in Lang's view, "the most ignorant, the most superstitious and the very lowest in the scale of European civilisation." 30 Though he hoped for universal suffrage and political autonomy for New South Wales, he was afraid to enfranchise Catholic men-all women were regarded as unsuitable voters - implying that they were less qualified than Protestantised, Indigenous men. He critiqued the rhetoric of his contemporary, James Macarthur, who had condemned "vile democracy" on the grounds that New South Wales might be forced to embrace "the cannibalism of the natives of New Zealand, and even admit the savages of this Colony to a share in the Government." Lang's newspaper pointed out that in New York, where male suffrage had been adopted, propertied men "as black as the Aborigines of this Territory, whose admission into the Colonial Constituency Mr. Macarthur is so much afraid of," had been granted the vote. No anarchy had resulted there. Lang was less enthusiastic, however, about the US law of naturalisation which, in Lang's view, allowed masses of illiterate Irish immigrants to influence elections. It was seemingly inconceivable to Lang that an immoral Catholic would be allowed a say in government when a propertied, Protestantised Indigenous man was denied it. ${ }^{31}$ He hoped that Protestant immigration would reform the colony's morals and render enfranchised Catholics less dominant.

Though genuinely concerned about the demise of Aboriginal Australia, in his republican manifesto, as Jessie Mitchell has observed, Lang nevertheless "positioned Aboriginal people's disappearance and political irrelevance within a broader narrative of progress that anticipated the rise of independent Australian government." 32 Now that the Indigenous people had all but disappeared, Lang maintained, Australia had few enemies and should be liberated (Lang had come to favour independence for the whole continent, not just Port Phillip). Lang was equally concerned, however, to bring about the disappearance of Catholicism from an independent Australia. Like Brazil, Lang argued, which had declared 
itself independent in 1822, Australia could become a moral commonwealth if it purged itself of oppressive Catholicism. ${ }^{33}$

Alexander Thomson, Scottish Presbyterian resident of Geelong, who wrote to Lang expressing his concern about Catholic migration to Port Phillip, ${ }^{34}$ seems to have agreed with Lang's views. Thomson reported to the Sydney legislature's select committee on immigration that Catholics were "utterly useless" and "in point of intellect... inferior to our own Aborigines." 35 Lang, Thomson and William Kerr sat on the board of the Port Phillip and Clarence River Colonization Company, established in 1849 to purchase government land and encourage a more exclusive system of immigration. ${ }^{36}$ Some separatists thus demanded Port Phillip's independence to stem the flow of Irish Catholic migrants, regarded as inhabiting a position lower in the racial scale than their Anglo-Saxon contemporaries, near or even below that held by Indigenous Australians.

It did not help that many of the migrants were unmarried. Anti-Catholicism was inflected with class, race and gender bias. During the 1830s the Colonial Office in London, with the aim of alleviating the alleged moral depravity for which New South Wales was so notorious, had sponsored the migration of single women to correct the sex imbalance in the colony. ${ }^{37}$ Many colonists, as Melanie Burkett has commented, condemned the women dispatched for their tendency to socialise with the convict underclass and for their failure to display the virtuous traits - sexual propriety, temperance, industriousness and passivityassociated with the burgeoning conception of middle-class femininity. ${ }^{38}$ Lang was particularly scornful of single women who travelled to Australia on their own. Only women lacking virtue, he thought, would expose themselves to the risk of a long and potentially dissipated sea voyage and the dangers of convict society on their arrival. Lang commented that "one bad woman let loose upon society does infinitely more harm than a dozen bad men" ${ }^{39}$ but Lang criticised in particular the migration of single, Catholic women. He hoped to encourage instead the migration of Protestants in order to facilitate Protestant marriages. Marriage, as Burkett has noted, was "the cornerstone of the developing middle-class ideal of respectability"; in Lang's view, Protestant married women were the "site of morality within the family" and within the colony as a whole. ${ }^{40}$

In 1849 Lang blamed Earl Grey, the new colonial secretary, for transporting over 2,000 Irish women migrants in the same year that he recommenced the transportation of criminals. 
The Colonial Office, Lang maintained, was intent on "Romanising" the colonies by orchestrating mixed marriages between Protestant men and Catholic women. The colony needed women to correct the imbalance of the sexes and it needed women to marry. But the colony needed the right type of women who would propagate bourgeois values within the confines of the family: Protestants (and Presbyterians if possible). In fact, as A.G.L. Shaw has pointed out, only 3,600 Irish migrants arrived in New South Wales in 1849 whereas 10,000 English men and women were dispatched. People of Irish descent amounted to between onequarter and one-third of the colony's population-roughly the same proportion they represented in the population of Britain and Ireland. ${ }^{41}$ A few years before in 1841, however, Irish women had constituted 70 percent of the total number of female migrants. ${ }^{42}$

A contemporary print by Edward Winstanley (b.1820), a Sydney-based artist, is indicative of contemporaries' preoccupations with increasing the Port Phillip population by fostering Protestant marriages. In this print the union between Port Phillip and New South Wales is personified as a dysfunctional relationship between a mother and her daughter. Winstanley depicts New South Wales as the matronly Georgiana, a convict woman and a representation of Governor George Gipps, who has handcuffed her youthful daughter Phillippina in front of Hyde Park Barracks. Georgiana implores her daughter to give up her "wanton ways" and support instead her mother's "weakly constitution", an illusion to the unionist accusation that separatists sought to subvert the British constitution. On the other side Phillippina begs her mother to let her go and live on her own resources in order better to protect her "blooming condition". On the side lines behind Phillippina stands John Dunmore Lang speaking in the Scots language. He accuses Georgiana of wanting to turn Phillippina into a nun. Georgiana, Lang quips, is "na muckle friend o' the kirk." 43 


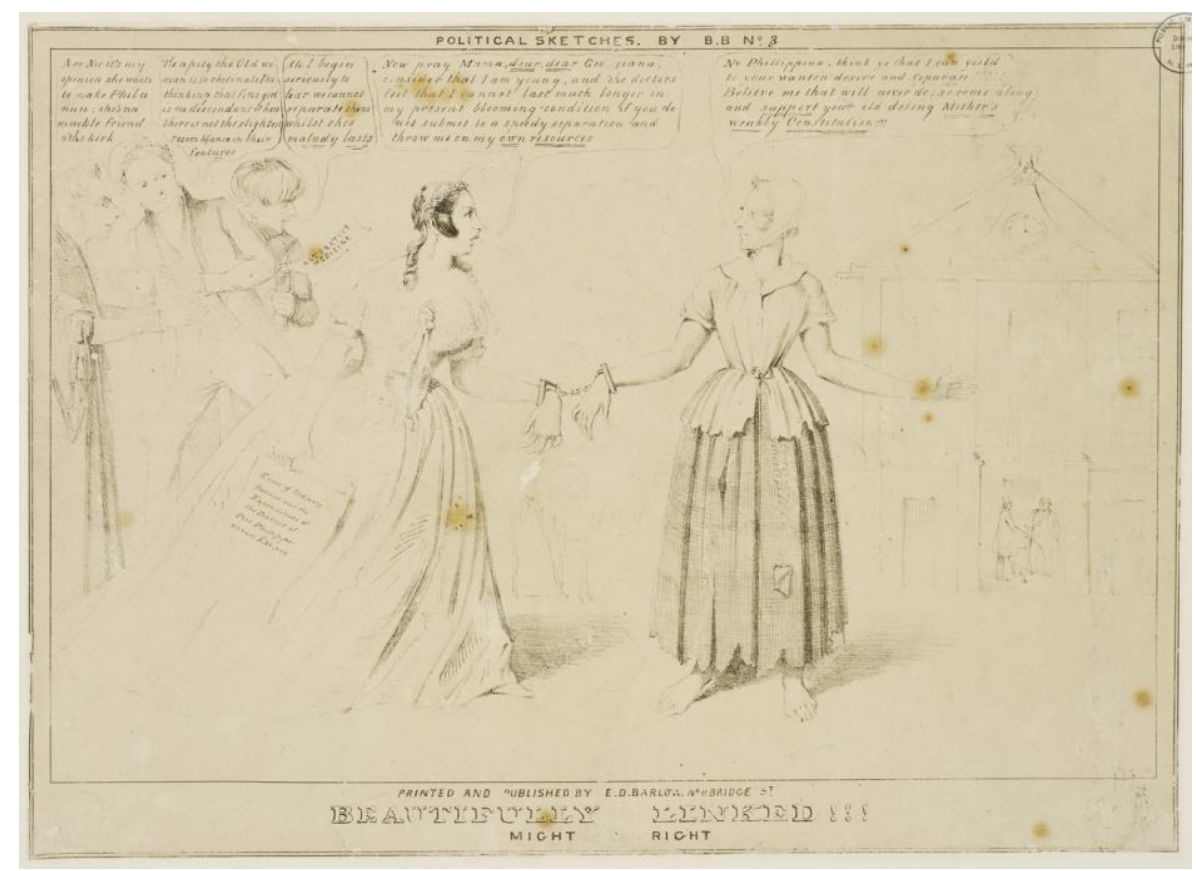

Figure 1. Beautifully Linked, Might v. Right: Edward Winstanley, ca. 1844, Raphael Clint \& Edward Barlow publishers, Dixson library, State Library of New South Wales, DL PXX 66.

The print implies that Port Phillip should be liberated from the taint of Sydney's convict past as well as from its Catholicism. Phillippina should be free to engage in sexual intercourse within the confines of marriage under the supervision of the Protestant-in this case Presbyterian - church. This print suggests that anti-convictism and anti-Catholicism were both central to the separation campaign. One could go further and submit that Port Phillip is here personified as a Scottish Presbyterian woman.

As scholars have pointed out, separatists compared Port Phillip's connection with New South Wales to an Indigenous marriage. By depicting Port Phillip as an abused, Indigenous woman, separatists attempted to discredit the union while underlining their civilised masculinity. ${ }^{44}$ "Colonial liberals," Leigh Boucher has written, "wove together notions of racial character and gendered capacity to justify claims for independence." 45 In one contemporary image, a personified Britannia separates two quarrelling children: Phillip is ordered by Britannia to go and "behave like a man."46 Ideas about manly independence underpinned Australian struggles over convict transportation, labour relations and political autonomy. ${ }^{47}$ As Marilyn Lake notes, "the self that claimed the right to self-government in British colonies of settlement was gendered and racialized in conception." ${ }^{48}$ But Winstanley's print suggests that 
besides being gendered and racialised, the self that claimed the right to self-government was also sectarian.

Winstanley's print underlines Lang's role in the separation campaign as well as the minister's concern, shared by some of his co-religionists, compatriots and fellow separatists, that union between Port Phillip and New South Wales was disadvantageous to the Scottish church in the region. Besides being coloured by class, race and gender bias, the discrimination against Irish Catholics, which was so central to the separation campaign, can also be attributed to Scottish Presbyterian values, particularly the doctrine of church-state separation and loyalist mythology imported from Ulster to Scotland. The next sections will discuss both in turn.

\section{Religious voluntaryism and the separation debate}

Lang, supported by William Kerr, who worked on Lang's Sydney-based newspaper before he moved to Melbourne, ${ }^{49}$ sought to separate Port Phillip from New South Wales in part to protect the Presbyterian church. Lang feared the dominance in New South Wales of the Church of England - whose bishop sat on the governor's legislative council—almost as much as he feared the influence of politicised Catholicism. Lang's political protest-his attempts to secure representative and responsible government for New South Wales, his commitment to Port Phillip's separation, and his eventual conversion to republicanism and Australian independence from Britain - can be partly attributed to his Scottish Presbyterian heritage. Lang was particularly influenced by the dissenting tenet of church-state separation, or voluntaryism as it was known, which, in Scotland, partly evolved from a Reformation-era critique of Catholicism and Anglicanism as systems which posed a threat to civil and religious liberty.

During the height of the separation campaign, voluntaryism, which called for churches to be supported voluntarily by congregations instead of by the state, had developed into a significant movement in Britain, spearheaded by Presbyterian dissenting churches in Scotland as well as by nonconformists in England and Wales. Indeed, one of the originators of the movement was a Scottish dissenting minister named the Rev. Andrew Marshall. Concerned that the emancipation of Catholics in 1829 might enable the Irish population to demand the establishment of the Catholic church, and tired of the civil disabilities from which dissenters from the national churches were said to suffer, Marshall preached a rousing and influential sermon calling for the disestablishment of the Church of England and Church of Scotland. Committed to the two-kingdoms doctrine of Scottish Presbyterianism-i.e. that the spiritual 
and temporal spheres should be separate - and fearful of hierarchical church government and its ties to the state, Scottish Presbyterian dissenters were arguably predisposed to admire voluntaryism. Though a member of the Church of Scotland, Lang converted to voluntaryism, resigning from his state-funded position as Presbyterian minister in Sydney and contributing propaganda to the voluntary crusade in Scotland. Lang was partly motivated by self-interest here- he had fallen out with his brethren and was due to be deposed — but he was also fully engaged with ecclesiological arguments emanating from the dissenting churches in Scotland. Lang had observed the voluntaryist system in operation in the United States and had been flirting with voluntaryism before the debacle of his threatened deposition. ${ }^{50}$

Lang called for Port Phillip's separation from New South Wales so that the voluntary system could be instituted in the newly autonomous region. Separation would give Port Phillip the chance to abolish the pluralist system established by Governor Bourke's Church Act of 1836. Under the provisions of the Church Act, which Lang had originally dubbed a new "Magna Carta" but which he grew to resent, $£ 30,000$ from the public revenue funded, at the time Lang was writing, five churches in New South Wales, including the Anglican and Catholic churches. This pluralist system introduced by Bourke, proclaimed Lang, legalised infidelity and it encouraged immoral conduct in his own Presbyterian denomination, whose ministers were lazy and unsatisfactory. It was also unfair, Lang argued, to expect colonists to fund churches in which they did not worship. ${ }^{51}$ Lang begrudged the dominant position held by Anglicans in New South Wales. ${ }^{52}$ Anglicans endorsed a hierarchical system of church governance and some of them had embraced Puseyism, a High-Church movement in the Church of England; thus, in the eyes of the Presbyterian lobby, they were borderline cryptoCatholics. ${ }^{53}$ According to Lang, the appointment in 1847 of Charles Perry as bishop for Port Phillip, incorrectly branded a Puseyite, would boost Catholicism. The Scots' overt antagonism to Anglicanism, pointed out Edward Curr, prominent Port Phillip sheep grazier and English Catholic, made a mockery of Lang's claims to be opposing Catholicism on behalf of "our common Protestantism."

Support for church disestablishment, inflected with anti-Anglicanism and antiCatholicism, reinforced the commitment of the Scots Presbyterian lobby to Port Phillip's independence from New South Wales. They were no doubt appalled that William Broughton, Anglican Bishop of Australia, denounced separation, arguing that it might encourage republicanism and threaten the position of Anglicanism. ${ }^{55}$ The Scots lobby also incorrectly 
assumed that the Anglican-backed La Trobe administration opposed separation and was being deliberately obstructive. ${ }^{56}$ In letters to Kerr's Port Phillip Patriot, Lang called on the residents of Port Phillip to support the voluntaryist movement ${ }^{57}$ and at a public meeting Kerr backed Lang's call for a free Presbyterian church in Port Phillip unconnected with the state. ${ }^{58}$ In a letter to the British Banner, moreover, Lang warned that once Port Phillip became independent, efforts to infuse the colony with the "two kindred apostacies of Popery and Puseyism" and establish numerous state churches would multiply. He pointed out that the imperial government intended to reserve $£ 6,000$ per annum for the maintenance of religious instruction in Port Phillip. Lang hoped to encourage those whom he pointedly described as "the right men — both ministers and people" to emigrate to Port Phillip and populate the province, hoping that they would abolish state aid and resist Catholic expansion. ${ }^{59}$

Like New South Wales, Lang thought, Ireland also was saddled with an oppressive and unpopular Anglican church establishment. As a result, Ireland, like Port Phillip, deserved its autonomy. Even Protestants in the north of Ireland, Lang maintained, would support repeal of the British-Irish union as there too Presbyterian Ulster-Scots had been subject to Anglican domination, a comment which indicates Lang's preoccupation with protecting the Presbyterian church and securing church disestablishment. To expect that Orangemen in the north, he suggested in a short-sighted statement, will "out of mere zeal for union and British connection

array themselves in active hostility against Repealers is preposterous." ${ }^{60}$ Lang hoped that once the British government had settled the Irish question, it might turn its attention to the colonies. Progress on granting Port Phillip its independence and self-government to all the Australian colonies had been too long delayed. ${ }^{61}$

\section{Orange loyalism in the separation campaign}

Scottish Presbyterian values - the anti-establishment voluntaryism of Scottish dissent, to which Lang subscribed - thus partly underpinned the anti-Anglican and anti-Catholic paranoia at the root of the separation campaign. Anti-Catholic Protestant mythology, imported from Ulster and influential in Scotland, also inspired Lang and his allies. Despite his belated support for Irish Repeal, discussed again below, Lang's separatist agenda and that of his associates, was partly expressed through the language of Orange loyalism. In Scotland, where there were seven lodges in the west of the country by 1813, Orangeism appealed because of a long-standing prejudice against Catholicism. Scots Presbyterians viewed Catholics as a threat to political stability and civil and religious liberty. The arrival of many poor Irish migrants in the 
nineteenth century, and the threatened politicisation of Catholics after emancipation, heightened this bias and strengthened the commitment of Presbyterian Scots to British union and to the British crown, a symbol of Protestant strength against the threat of Irish republicanism. Scottish Unionism emerged as a political creed in the nineteenth century. A reaction against the growth of Irish nationalism and bolstered by the Orange Order, Unionism was "inescapably linked to Protestant sectarianism."62

Though Orange loyalism, as scholars have pointed out, acted as an agent for "imperial integration," as a locally specific phenomenon, loyalism also had the potential to facilitate the growth of national independence movements. ${ }^{63}$ Indeed, in Scotland some Presbyterians embraced Unionism to protect Scotland's distinctive religious institutions from the perceived threat of Irish Catholicism. Unionism had a nationalist flavour. In the Port Phillip settlement, meanwhile, some Scottish separatists used the language of Ulster loyalism to battle for independence. Though Orange lodges in Australia were "forums for Ulster Protestant" identity, as Dianne Hall has argued, ${ }^{64}$ they incorporated Scottish as well as Irish migrants, including the formidable William Kerr of Melbourne. According to Ben Wilkie's recent findings, by the second half of the nineteenth century, Scottish associational culture in Melbourne exhibited a "hybrid form of British loyalty and Scottish nationalism": what can be described as "popular imperialism." 65 At Robert Burns festivals, which were organised by William Kerr, Melbourne Scots celebrated their "unionist nationalism." These festivals, Alex Tyrrell suggests, gave Lang and his compatriots a platform from which to promote their exclusionary values and separatist agenda. ${ }^{66}$ The independence that this lobby sought was not that of a fully autonomous sovereign state: they envisioned political autonomy for Port Phillip within the larger polity of Britain's empire. For Lang, however, the vision of imperial federation was soon eclipsed by the dream of republicanism and full independence from Britain, this time for Australia as a whole. Whereas in Scotland Protestant loyalism underpinned the commitment of some to maintaining the union with England and strengthening the British state and British crown, in Australia - for Lang at least - it partly originated demands for republican nationalism. While, as Donal Lowry has pointed out, the faith and ethnicity of Irish Catholic Australians constituted no barrier to their embrace of "empire loyalism," Lang's religious views were central first to his approach to separation and then to his republicanism. ${ }^{67}$ 
The influence of loyalist mythology can be discerned in the bitter election campaigns fought in Port Phillip — campaigns coloured by sectarianism and during which the issue of separation came to the fore. Port Phillip gained representation in the blended thirty-six-member legislative council established at Sydney in 1842. During one of his visits to Melbourne, the Separation Committee nominated Lang for election to one of the non-Melbourne seats while Edward Curr, the prominent Catholic settler and supporter of separatism, was nominated for the Melbourne seat. Curr was understandably indignant at Lang's recent anti-Catholic polemic. Brandishing a copy at a public meeting of Lang's newly published pamphlet, The Question of Questions; or, is this Colony to be transformed into a Province of the Popedom?, Curr insisted that he could not sit on a council of which Lang was a member. At the eleventh hour, to prevent Curr from "establishing a Roman ascendancy" in Port Phillip, Lang and Kerr decided to demolish Curr's election campaign by introducing a candidate to stand against him. ${ }^{68}$ Under cover of darkness they visited the house of Henry Condell and urged him to join the race for the Melbourne seat. Reluctant at first, Lang's offer to write his speeches and mastermind the campaign won Condell over. By two o'clock on the following day, Lang and Kerr had collected 250 signatures endorsing Condell's nomination. In his nomination speech Condell recommended separation and "immigration into Port Phillip with Port Phillip money," a dog whistle to the anti-Catholic voters in the room. ${ }^{69}$ Lang campaigned on Condell's behalf, delivering a lecture in the Mechanics' Institute on the $11^{\text {th }}$ June in which he reportedly implored the audience to vote for a Protestant candidate in order to extirpate Catholicism "from the face of the earth." 70

Exasperated at the introduction of sectarianism into Melbourne politics and incredulous when Lang disingenuously claimed that he had no objection to Curr's faith, ${ }^{71}$ Curr accused the Presbyterian lobby of religious bigotry and denounced their electioneering subterfuge as "a declaration of a war of religions." In a letter to the Australasian Chronicle, he recorded the slogan from a campaign placard printed at the office of Kerr's Port Phillip Patriot: "Protestant Electors of Melbourne! Remember what your forefathers have suffered from Popery; and will you again give it the ascendancy by returning a Popish member for Melbourne? You are three to one in number; so down with the rabble, and no surrender [my italics]." ${ }^{, 72}$ His opponents, Curr argued, had chosen a loyalist slogan which Irish Catholics recognised as representing slaughter and oppression. ${ }^{73}$ 
Though mocked for being Lang's puppet, Condell defeated Curr by 295 votes to $261 .^{74}$ Catholic voters complained of corruption and the protest turned violent. Condell's house was attacked and two men were wounded. According to Lang, a "furious assemblage" of "Tipperary Boys," whose ire was dampened only by the intercession of Curr, led the protest. This circumstance proved not that the Catholic community had a legitimate grievance, argued Lang, but showed "what atrocities would be perpetrated without hesitation to secure and perpetuate Romish ascendancy."75 Lang alleged that these Tipperary Boys had been brought out in their hundreds under the Protestant-funded bounty system. This incident highlighted that Port Phillip must regain control of its immigration policy in a semi-autonomous separate state.

In response to this Catholic mobilisation, William Kerr and his associates founded a branch of the Orange Order in Melbourne; Kerr acted as its first treasurer. ${ }^{76}$ Their $12^{\text {th }}$ July celebrations in 1846, when Orangemen gathered for a dinner in the Pastoral Hotel and hung loyalist flags, generated civil unrest. Outraged protesters stormed the hotel's lobby, a man was reportedly shot in the cheek ${ }^{77}$ and the town was in a "state of anarchy" for two days. ${ }^{78}$ The authorities ordered the removal of the flags and cancelled the dinner. Kerr's Argus defended the Orangemen and denounced the authorities' response. The piece ended with rousing verses entitled "The Protestant Warning," reportedly written by "Cromwell's Ghost." These verses called on Melbourne Orangemen to resist the incursions of the Romish mob and equated these local troubles with well-known episodes in Protestant loyalist mythology including the "Ninety-Eight," when "our fathers... upheld the British Throne," and the Williamite war of 1688-90. ${ }^{79}$ In 1847 the New South Wales legislature passed the Party Processions Act to curb sectarian activity. William Kerr laid the foundation stone of a new "Protestant Hall," defiantly erected in 1848 and designed to stage celebrations against "Popish" tyranny and the "incapacity of the constituted authorities" to contain it. ${ }^{80}$

Though, Lang stated, he was no Orangeman himself, he jumped to the defence of Kerr and his allies. As in 1843, the "Irish Roman Catholic Bounty Immigrant mob" had perpetrated this recent violence and "maltreated" the Orangemen. Lang now redoubled his efforts to encourage Protestant immigration to Port Phillip by embarking on a lecture tour in northern Ireland. He drafted a petition to the Colonial Office on behalf of the "Protestant inhabitants" of Port Phillip. To protect civil and religious liberty and inspire good government in the district, Lang urged, separation was essential. Thus far the "spirit of British freedom and manly 
independence" had been "retarded." 81 While Lang pressed for separation to root out Catholicism, Edward Curr believed that only separation could stamp out Orangeism. He publicly denounced Lang's petition and "sectarian immigration" plans and objected to Lang's attempts to define "virtue" as an exclusively Protestant trait exhibited in Ireland only in the north. ${ }^{82}$ Curr, however, implicitly accepted the alleged correlation between Irish Catholicism and indecency when he rejected the label "Irish mob leader" and defined himself as a "true English conservative". ${ }^{83}$ The sectarian violence stiffened his resolve and he continued to press for separation fearing that Orange bigotry would become even more pronounced if independence was denied. ${ }^{84}$ "I defy a deputy absentee government," said he, "to maintain peace between the orange malignants of the corporation, and their much abused and insulted opponents." 85

Lang and his allies tried to discredit Curr by comparing him to Daniel O'Connell. ${ }^{86}$ Lang originally distanced the separation campaign from the movement to repeal the union between Britain and Ireland. ${ }^{87}$ Later, however, as we have already seen, he had more sympathy for Repeal, hoping that Irish independence would keep Irish Catholics in Ireland and out of Britain and its colonies. Lang believed that like the Irish, Australians had a right to autonomy, claiming that "the case of Ireland, as a constituent part of the United Kingdom, is precisely the same in principle as that of Port Phillip, as a constituent part of the colony of New South Wales." ${ }^{88}$ Lang was coming increasingly to embrace republicanism and the independence not just of Port Phillip but of Australia as a whole. In 1849 Lang warned Earl Grey, the colonial secretary, that the recent resumption of transportation had generated a desire for republicanism. Earl Grey had become increasingly objectionable to Lang and the residents of Port Phillip, who, to highlight the absurdity of absentee rule, had, in 1848, elected him to the Sydney legislature as member for Melbourne. Lang depicted Earl Grey, a symbol of imperial dominance, as a "political Pope" who usurped the rights of men and God by heading an empire which aspired to universal dominion. ${ }^{89}$ Australia must divorce itself from a Romanising empire unable or unwilling to protect its Protestant subjects.

Thus, by mid-century, partly inspired by the anti-Catholic values of Scottish Presbyterianism, John Dunmore Lang had become an outspoken champion of Australia's full independence from Britain and its monarchy. Lang could be described as something which seems anomalous today: a republican who sympathised with Orangeism. In Scotland, antiCatholic loyalism historically underpinned the commitment of Orangemen to unionism; British 
union under a Protestant British crown, it was argued, safeguarded Scottish institutions from the infiltration of Irish Catholicism. This strand of unionism has endured; a survey conducted in 1990 suggested that only seven percent of the Orangemen surveyed supported Scottish independence. ${ }^{90}$ In 1840s Melbourne, Scottish Presbyterians who protested the immigration of Irish Catholics, were also attracted to Orange loyalism. Unlike in Scotland, where Orangeism strengthened commitment to British union, Melbourne loyalism underpinned demands for separation and then, in Lang's case, republicanism and Australian independence. Lang's position is perhaps less anomalous when one considers the Australian context of republicanism. Here, republicanism drew on British traditions - in Lang's case, his Scottish Presbyterian heritage — while Irish Catholics could be found in the loyalist ranks. ${ }^{91}$

\section{Conclusion}

As support for separatism in Europe grows, and as Brexit Britain ponders its constitutional future, it becomes increasingly important for historians to examine separatist movements of the past. The moment is apt for revisiting the Port Phillip campaign, a debate which, as A.G.L. Shaw noted back in 1982, raised questions concerning the utility of local government and the benefits of federalism. ${ }^{92}$ It was also a debate, this paper has suggested, in which the construction of otherness formed an integral component of separatist discourse. The rhetoric of the Indigenous other, as Jessie Mitchell has argued, helped to forge a unifying settler identity and further Port Phillip's campaign for political autonomy. But the prevalence in the separatist movement of anti-Catholicism indicates that settlers were not as homogenous as suggested by the symbolism on show at the celebratory Yarra parade. The Scots Presbyterians at the forefront of the separation campaign, inspired by Presbyterian values-including the doctrine of church-state separation and loyalist mythology - were afraid of Catholicism. In the early Victorian period, on account of their poverty and alleged immorality, Catholics-Irish single women in particular - threatened the colony's aspirations to bourgeois respectability. Just as the "rule of difference" excluded Catholics from citizenship in the eighteenth-century Atlantic world, ${ }^{93}$ so the discourse of respectability marginalised Catholics in colonial New South Wales. They were regarded by some as uncivilised and as unfit for political citizenship as Indigenous Australians; Catholics undermined attempts to represent Port Phillip as urbane, progressive and ready for self-rule. An analysis of separatist rhetoric suggests that in the colonial British world class, race, gender and religion could be intersectional. It also serves as a reminder that constructs of self and others, as Robert Thomsen has noted, have ever been utilised to legitimise political separatism, anti-migrant policies and demands for constitutional change. ${ }^{94}$ 
For correspondence: valerie.wallace@vuw.ac.nz. I would like to thank Tim Causer for his helpful comments on an earlier draft.

Notes

${ }^{1}$ William Westgarth, Australia Felix; or, a historical and descriptive account of the settlement of Port Phillip, New South Wales (Edinburgh: Oliver \& Boyd, 1848), 343.

${ }^{2}$ [Committee of the Separation Society,] The Petitions of the District of Port Phillip, (Australia Felix, ) For Separation From the Territory of New South Wales (Melbourne: W. Clarke, 1844), iv.

3 “Colonial Politics," Colonial Observer, 26 Dec. 1844.

${ }^{4}$ The Petitions.

5 "The Complaint of Our Port Phillip Subscribers," The Colonist, 20 July 1839.

6 “Separation Rejoicings," The Argus, 19 Nov. 1850.

${ }^{7}$ Jessie Mitchell, “"The Galling Yoke of Slavery’: Race and separation in colonial Port Phillip,” Journal of Australian Studies 33/2 (2009): 125-37. See also Jessie Mitchell, “"Are We in Danger of a Hostile Visit from the Aborigines?' Dispossession and the rise of selfgovernment in New South Wales," Australian Historical Studies 40/3 (2009): 294-307; "Introductory Remarks," The Petitions, iii.

${ }^{8}$ Kerr recommended that aldermen for Melbourne be selected from the elected councillors; as a result, five out of six of the first aldermen were also Scots: Cliff Cumming, "Scots Radicals in Port Phillip 1838-1851," Australian Journal of Politics and History 37 (1991): 434-45. ${ }^{9}$ William Westgarth, Personal Recollections of Early Melbourne and Victoria, Project Gutenberg Ebook, May 2004, Edition 10, http://www.gutenberg.org/files/5789/5789.txt, n.p. ${ }^{10}$ For a summary of Lang's involvement see D.W.A. Baker, Days of Wrath: A life of John Dunmore Lang (Melbourne: Melbourne University Press, 1985), 192-201.

${ }^{11}$ See e.g. Hilary M. Carey, "Clerics and the Beginning of the Anti-Transportation Debate," in David Andrew Roberts, "Beyond 'the Stain': Rethinking the nature and impact of the antitransportation movement," Journal of Australian Colonial History 14 (2012): 241-249; Benjamin T. Jones, Republicanism and Responsible Government: The shaping of democracy in Australia and Canada (Montreal/Kingston: McGill-Queen's University Press, 2014); 
Valerie Wallace, Scottish Presbyterianism and Settler Colonial Politics: Empire of dissent (Cham: Palgrave Macmillan, 2018).

${ }^{12}$ Kirsten McKenzie, Scandal in the Colonies: Sydney and Cape Town, 1820-1850 (Melbourne: Melbourne University Press, 2004), 11. See also P. Russell, Savage or Civilised? Manners in colonial Australia (Sydney: University of New South Wales Press, 2010).

${ }^{13}$ The Petitions, 12.

${ }^{14}$ The Colonial Office disallowed the legislation claiming it was unconstitutional: Stefan Petrow, "Convict-phobia': Combating Vandemonian convicts in 1850s and 1860s Victoria," in Roberts, "Beyond 'the Stain'," 260-71.

${ }^{15}$ Mitchell, "'The Galling Yoke of Slavery"”; Mitchell, "Dispossession and the Rise of SelfGovernment."

${ }^{16}$ Though see Paula Hamilton, “"Tipperarifying the Moral Atmosphere': Irish Catholic immigration and the state 1840-1860," in Sydney Labour History Group, What Rough Beast? The state and social order in Australian history (Sydney: Allen \& Unwin, 1982), 13-30. 17 “Colonial Census," The Colonist, 9 Feb. 1837.

18 "Review of the Census," The Colonist, 16 Feb. 1837.

${ }^{19}$ Carey, “Anti-Transportation Debate,” 241-49.

${ }^{20}$ Jessica L. Harland-Jacobs, “Incorporating the King’s New Subjects: Accommodation and anti-Catholicism in the British Empire, 1763-1815," Journal of Religious History 39/2 (2015): 203-23.

${ }^{21}$ S. Karly Kehoe, "Catholic Relief and the Political Awakening of Irish Catholics in Nova Scotia, 1780-1830," Journal of Imperial and Commonwealth History 46/1 (2018): 1-20. ${ }^{22}$ John Wolffe, “Anti-Catholicism and the British Empire, 1815-1914,” in Empires of Religion, edited by Hilary M. Carey (Basingstoke: Palgrave Macmillan, 2008), 43-63, at 45. ${ }^{23}$ Catherine Hall, "The Rule of Difference: Gender, class and empire in the making of the 1832 Reform Act," in Gendered Nations: Nationalism and gender order in the long nineteenth century, edited by Ida Blom, Karen Hagemann and Catherine Hall (Oxford and New York: Bloomsbury, 2000), 107-35, at 117.

${ }^{24}$ John Belchem, "Radical Language, Meaning and Identity in the Age of the Chartists," Journal of Victorian Culture 10/1 (2005): 1-14, at 6.

${ }^{25}$ See e.g. Robert Ross, Status and Respectability in the Cape Colony, 1750-1870: A tragedy of manners (Cambridge: Cambridge University Press, 1999), 116. 
${ }^{26}$ John Dunmore Lang, Repeal or Revolution; or, a glimpse of the Irish future in a letter to the right honourable Lord John Russell (London: Effingham Wilson, 1848), 36-37.

${ }^{27}$ John Dunmore Lang, Historical Account of the Separation of Victoria from New South Wales (Sydney: John L. Sherriff, 1870), 10-11.

${ }^{28}$ John Dunmore Lang, Emigration; Considered Chiefly in Reference to the Practicability and Expediency of Importing and of Settling throughout the Territory of New South Wales (Sydney: E.S. Hall, 1833), 14.

${ }^{29}$ Dianne Hall, “"Now Him White Man’: Images of the Irish in colonial Australia,” History Australia 11/2 (2014): 167-95, at 167.

${ }^{30}$ Lang, Emigration, 14.

${ }^{31}$ John Dunmore Lang, The Question of Questions! Or, is this colony to be transformed into a province of the popedom? A letter to the Protestant landholders of New South Wales (Sydney: J. Tegg \& Co., 1841), 3-46.

${ }^{32}$ Mitchell, “"The Galling Yoke of Slavery',” 304.

${ }^{33}$ John Dunmore Lang, Freedom and Independence for the Golden Lands of Australia (London: Longman, Brown, Green, and Longmans, 1852), 75-77

${ }^{34}$ State Library of Victoria, Alexander Thomson Papers, MS 9345, Box 1033/1, Thomson to Lang, 1 March 1846.

${ }^{35}$ Lang, Historical Account, 10.

${ }^{36}$ State Library of Victoria, Alexander Thomson Papers, Box 1034/4(d), "Port Phillip and Clarence River Colonization Company."

${ }^{37}$ On female migration see Deborah Oxley and Eric Richards, "Convict Women and Assisted Female Immigrants Compared: 1841—a turning point?," in Visible Women: Female immigrants in colonial Australia, edited by Eric Richards (Canberra: Division of Historical Studies and Centre for Immigration and Multicultural Studies, The Australian National University, 1995), 1-58.

${ }^{38}$ For attitudes to convict women see Joy Damousi, Depraved and Disorderly: Female convicts, sexuality and gender in colonial Australia (Cambridge: Cambridge University Press, 1997); Anne Summers, Damned Whores and God's Police (Ringwood, Victoria: Penguin, 1994), 313-62.

${ }^{39}$ Quoted in A.J. Hammerton, “'Without Natural Protectors': Female immigration to Australia, 1832-36," Australian Historical Studies 16/65 (1975): 539-66, at 557. ${ }^{40}$ Melanie Burkett, "Shifting and Colliding Conceptions of 'Respectability': Why single female emigration to New South Wales was doomed to disappoint," unpublished conference 
paper presented at the First Eric Richards Symposium, Flinders University, Adelaide, January 2017.

${ }^{41}$ A.G.L. Shaw, A History of the Port Phillip District: Victoria before separation (Melbourne: Melbourne University Press, 1996), 206.

${ }^{42}$ Oxley and Richards, "Female Immigrants Compared," 26.

${ }^{43} 8$ political lithographic cartoons, mostly by Edward Winstanley, published in Sydney in the 1840s / Raphael Clint \& Edward Barlow publishers, Dixson library, State Library of New South Wales:

http://digital.sl.nsw.gov.au/delivery/DeliveryManagerServlet?dps_pid=FL991392\&embedde $\mathrm{d}=$ true \& toolbar=false.

${ }^{44}$ Mitchell, “"The Galling Yoke of Slavery"”; Mitchell, "Dispossession and the Rise of SelfGovernment."

${ }^{45}$ Leigh Boucher, "Race, Rights and the Re-forming Settler Polity in Mid-nineteenth-century Victoria," Journal of Australian Colonial History 15 (2013): 83-104, at 93.

${ }^{46}$ Mitchell, “"The Galling Yoke of Slavery'," 132.

${ }^{47}$ Angela Woollacott, “A Radical's Career: Responsible government, settler colonialism and Indigenous dispossession,” Journal of Colonialism and Colonial History 16/2 (2015).

${ }^{48}$ Marilyn Lake, "The Gendered and Racialized Self who Claimed the Right to SelfGovernment," Journal of Colonialism and Colonial History 13/1 (2012). See also Leigh Boucher, "Victorian Liberalism and the Effect of Sovereignty: A view from the settler periphery," History Australia 13/1 (2016): 35-51; Angela Woollacott, Settler Society in the Australian Colonies: Self-government and imperial culture (Oxford: Oxford University Press, 2015), 7.

${ }^{49}$ Westgarth, Personal Recollections, n.p.

${ }^{50}$ For evidence of Lang's voluntaryism see John Dunmore Lang, Three Lectures, on the Impolicy and Injustice of Religious Establishments, or the granting of money for the support of religion from the public treasury, in the Australian Colonies (Sydney: Robert Barr, 1856). For the development of voluntaryism in Scotland and Lang's contribution, see Wallace, Scottish Presbyterianism and Settler Colonial Politics, chap. 10.

${ }^{51}$ John Dunmore Lang, Phillipsland; or the County Hitherto Designated Port Phillip: Its present condition and prospects, as a highly eligible field for emigration (London: Longman, Brown, Green, and Longmans, 1847), 421.

52 “Colonial Politics," Colonial Observer, 1 June 1842.

53 “The Puseyite Heresy,” Melbourne Courier, 18 June 1845. 
54 "Mr. Curr's Letter, to the Editor of the Port Phillip Herald," Australasian Chronicle, 6 July 1843.

55 The National Archives [TNA], CO 201/375, Proceedings of the Executive Council on 18 and 23 April relative to the erection of the Port Phillip District into a separate Colony.

Extract from Minute dated 1 April 1846; A.G.L. Shaw, ed., Gipps-La Trobe Correspondence 1839-1846 (Melbourne: Melbourne University Press, 1989), 382; Shaw, A History, 244.

${ }^{56}$ In fact La Trobe, and eventually Governor Gipps, conceded that separation was desirable, though Gipps thought the economic argument to be weak: TNA, CO 201/375, Gipps to Lord Stanley 29 April 1846; Shaw, ed., Correspondence, 272, 280, 293.

57 “'Original Correspondence,” Port Phillip Patriot, 3 March 1845.

58 “Public Meeting for the Formation of a Free Presbyterian Church in Port Phillip,

Unconnected with the State," Port Phillip Patriot, 10 March 1845.

59 "Port Phillip and the Present Crisis," The British Banner, 20 June 1849.

${ }^{60}$ Lang, Repeal or Revolution, 14-15, 27.

${ }^{61}$ Lang, Repeal or Revolution, 36-7.

${ }^{62}$ Colin Kidd, Union and Unionisms: Political thought in Scotland, 1500-2000 (Cambridge: Cambridge University Press, 2008), 14; Graham Walker, "Varieties of Scottish Protestant Identity," in Scotland in the Twentieth Century, edited by Tom M. Devine and Richard J. Finlay (Edinburgh: Edinburgh University Press, 1996), 250-68, at 260.

${ }^{63}$ Frank O'Gorman and Allan Blackstock, "Loyalism and the British World: Overviews, themes and linkages," in Loyalism and the Formation of the British World, 1775-1914, edited by Allan Blackstock and Frank O’Gorman (Woodbridge: Boydell and Brewer, 2014), 11.

${ }^{64}$ Dianne Hall, "Defending the Faith: Orangeism and Ulster Protestant identities in colonial New South Wales," Journal of Religious History 38/2 (2014): 207-23.

${ }^{65}$ Ben Wilkie, The Scots in Australia, 1788-1938 (Woodbridge: Boydell and Brewer, 2017), 79. See also Alex Tyrrell, "Scottishness and Britishness From Scotland to Australia Felix," Humanities Research 13/1 (2006): 17-26.

${ }^{66}$ Alex Tyrrell, "'No Common Corrobery': The Robert Burns Festivals and identity politics in Melbourne, 1845-59," Journal of the Royal Australian Historical Society 97/2 (2011): $161-80$.

${ }^{67}$ Donal Lowry, "The Crown, Empire Loyalism and the Assimilation of Non-British White Subjects in the British World: An argument against 'ethnic determinism'," The Journal of Imperial and Commonwealth History 31/2 (2003): 96-120, at 111. 
${ }^{68}$ Lang, Historical Account, 12.

69 “Original Correspondence,” Australasian Chronicle, 16 August 1843.

70 "Port Phillip," Australasian Chronicle, 27 June 1843.

71 “Colonial Politics,” Colonial Observer, 12 July 1843.

72 “Original Correspondence,” Australasian Chronicle, 16 August 1843.

73 "Mr. Curr's Letter, to the Editor of the Port Phillip Herald," Australasian Chronicle, 6 July 1843.

${ }^{74}$ Samuel Furphy, Edward M. Curr and the Tide of History (Canberra: ANU Press, 2013), 47.

${ }^{75}$ Lang, Phillipsland, 367; see also “Colonial Politics,” Colonial Observer, 5 July 1843.

${ }^{76}$ Richard P. Davis, "Loyalism in Australasia, 1788-1868," in Loyalism, ed. Blackstock and O’Gorman, 233.

${ }^{77}$ Thomas McCombie, The History of the Colony of Victoria: From its settlement to the death of Sir Charles Hotham (Melbourne: Sands and Kenny, 1858), 119. There had been unrest the year before: "The Ribbon Boys," Melbourne Courier, 16 July 1845.

${ }^{78}$ Lang, Phillipsland, 368.

79 “The Late Popish Riots,” Melbourne Argus, 24 July 1846.

80 “Domestic Intelligence," Melbourne Argus, 15 Feb 1848. See also Tas Vertigan, The Orange Order in Victoria (Melbourne: Loyal Orange Institution of Victoria, 1979), 24-25. ${ }^{81}$ Lang, Phillipsland, 367-69; see also “The July Riots,” Melbourne Argus, 4 June 1847. 82 “Dr. Lang Once More!,” Morning Chronicle, 28 March 1846. The Port Phillip Herald agreed with Curr and insisted that the need for immigrant labour was so acute that it mattered not whether the migrants were Protestant or Catholic: “"Party' Immigration,” Morning Chronicle, 4 April 1846.

83 “Mr. Curr's Letter, to the Editor of the Port Phillip Herald," Australasian Chronicle, 6 July 1843.

84 "Curr, Edward (1798-1850)," Australian Dictionary of Biography, National Centre of Biography, Australian National University, published first in hardcopy 1966, accessed 19 December 2014, http://adb.anu.edu.au/biography/curr-edward-1944/text2331. 85 "Mr. Curr's Letter, to the Editor of the Port Phillip Herald," Australasian Chronicle, 6 July 1843.

${ }^{86}$ Lang, Phillipsland, 368; Colonial Observer, 21 Sep 1842.

${ }^{87}$ See e.g. "Debate in the Legislative Council on the Separation Question. Tuesday, August 20, 1844," in The Petitions, 27. 
${ }^{88}$ Lang, Repeal or Revolution, 14-15, 27.

${ }^{89}$ Lang, Historical Account, Postscript, 3.

${ }^{90}$ J.M. Bradley, “Orangeism in Scotland: Unionism, Politics, Identity, and Football,” ÉireIreland 39/1\&2 (2004): 237-61, at 251.

${ }^{91}$ Lowry, "The Crown, Empire Loyalism."

92 A.G.L. Shaw, "Agitation for the Separation of the Port Phillip District from the Colony of New South Wales, 1838-1850," Journal of the Royal Australian Historical Society 68/1 (1982): $1-17$, at 1 .

${ }^{93}$ Jerry Bannister, “The Oriental Atlantic: Governance and regulatory frameworks in the British Atlantic World," in Britain's Oceanic Empire: Atlantic and Indian Ocean worlds, $c$. 1550-1850, edited by H.V. Bowen, Elizabeth Mancke and John G. Reid (Cambridge: Cambridge University Press, 2012), 151-76.

${ }^{94}$ Robert C. Thomsen, Nationalism in Stateless Nations: Images of self and other in Scotland and Newfoundland (Edinburgh: John Donald, 2010), 2. 